\title{
SARS-CoV-2 Myocarditis: Insights Into Incidence, Prognosis, and Therapeutic Implications
}

\author{
Ossama K. Abou Hassan ${ }^{1} \cdot$ Calvin C. Sheng ${ }^{1} \cdot$ Tom Kai Ming Wang $^{1} \cdot$ Paul C. Cremer $^{1}$ (B) \\ Accepted: 11 April 2021 / Published online: 3 August 2021 \\ (C) The Author(s), under exclusive licence to Springer Science+Business Media, LLC, part of Springer Nature 2021
}

\begin{abstract}
Purpose of Review In coronavirus disease 2019 (COVID-19), myocardial injury occurs frequently in severe or critically ill hospitalized patients, yet myocarditis is much less common. In this context, revisiting the definition of myocarditis is appropriate with a specific focus on diagnostic and management considerations in patients infected with SARS-CoV-2.

Recent Findings Pathologic cardiac specimens from patients with COVID-19 suggest a mixed inflammatory response involving lymphocytes and macrophages, and importantly, cellular injury occurs predominantly at the level of pericytes and endothelial cells, less often involving direct myocyte necrosis. In COVID-19, the diagnosis of myocarditis has understandably been based predominantly on clinical criteria, and the number of patients with clinically suspected myocarditis who would meet diagnostic histological criteria is unclear. Echocardiography and cardiac magnetic resonance are important diagnostic tools, although the prognostic implications of abnormalities are still being defined. Importantly, SARS-CoV2 myocarditis should be diagnosed within an appropriate clinical context and should not be based on isolated imaging findings. Therapies in COVID-19 have focused on the major clinical manifestation of pneumonia, but the promotion of viral clearance early in the disease could prevent the development of myocarditis, and further study of immunosuppressive therapies once myocarditis has developed are indicated.

Summary A strict and uniform approach is needed to diagnose myocarditis due to SARS-CoV-2 to better understand the natural history of this disease and to facilitate evaluation of potential therapeutic interventions. A methodological approach will also better inform the incidence of COVID-19 associated myocarditis and potential long-term health effects.
\end{abstract}

Keywords SARS-CoV-2 $\cdot$ COVID-19 $\cdot$ Myocardial injury $\cdot$ Myocarditis $\cdot$ COVID-19 therapy

\section{Introduction}

Myocarditis can be simply considered as an inflammatory response within the myocardium. In developed countries, the

This article is part of the Topical Collection on Myocardial Disease

\section{Paul C. Cremer}

cremerp@ccf.org

Ossama K. Abou Hassan

abouhao@ccf.org

Calvin C. Sheng

shengc@ccf.org

Tom Kai Ming Wang

wangt2@ccf.org

1 Section of Cardiovascular Imaging, Robert and Suzanne Tomsich Department of Cardiovascular Medicine, Sydell and Arnold Miller Family Heart and Vascular Institute, Cleveland Clinic,

Cleveland, OH 44195, USA most frequent inciting event is a viral infection, though primary immune and toxic causes are also common. Typically, after viral entry into myocytes, humoral, and cellular immune responses mediated by macrophages and lymphocytes help to eliminate the infectious agent within days to weeks. However, in susceptible immune systems, viral genome persists, as does the inflammatory response [1,2]. In certain cases, an autoimmune response may perpetuate continuous inflammation and progressive myocardial damage [3].

The viruses most commonly implicated in myocarditis include Influenza viruses, Enterovirus, Adenovirus, Human Herpes Virus-6, Cytomegalovirus, Epstein-Barr-Virus, Hepatitis C virus, and Parvovirus B19 [4-10]. Of note, myocarditis due to Coronavirus has been described, but less frequently, and coronavirus has not been previously considered cardiotropic [11]. However, interest in coronavirus-associated myocarditis has heightened as the global pandemic due to SARS-CoV2 has resulted in increasing deaths related to 
respiratory and cardiovascular complications [12-14]. In coronavirus disease 2019 (Covid-19), multiple causes of myocardial injury have been identified, such as oxygen supplydemand mismatch, stress cardiomyopathy, pro-thrombotic and microvascular disease, direct viral myocardial injury, and a systemic hyper-inflammatory response with myocardial involvement [15-18]. These various causes of myocardial injury are often loosely referred to as myocarditis, although myocarditis more specifically refers to direct viral injury and associated inflammation.

In SARS-CoV2 associated myocarditis, whether the same histochemical, clinical, imaging, and prognostic markers can be applied from other forms of viral myocarditis is uncertain. In addition, therapeutic options which may provide benefit in COVID-19 associated myocarditis are unclear. Specifically, the applicability of encouraging data in severe COVID-19 pneumonia with remdesivir and dexamethasone to patients with myocarditis is unknown $[19,20]$. In this review, the diagnosis of myocarditis in the context of SARS-CoV-2 infection is evaluated, highlighting the importance of a standardized definition and diagnosis. Potential prognostic implications and therapeutics are also discussed.

\section{Defining Myocarditis}

Myocarditis is defined as an inflammatory disease of the myocardium diagnosed by a combination of histological, immunological, and immunohistochemical criteria [21]. The histologic classification is traditionally based on the Dallas Criteria which requires evidence of "inflammatory infiltrates within the myocardium associated with myocyte degeneration and necrosis of nonischemic origin" [22]. The inflammatory cells may be classified according to the type of infiltrate: lymphocytic, eosinophilic, polymorphic, giant cell myocarditis, and granulomas typical of cardiac sarcoidosis. Importantly, viral genome may be within the myocardium without an associated inflammatory response. Although widely employed, there are concerns related to the diagnostic accuracy of the Dallas Criteria. For one, sensitivity is limited because myocarditis may be focal or predominantly epicardial which reduces the yield of endomyocardial biopsy, although increasing the number of samples obtained does increase sensitivity [6, 23-25]. In addition, inter-reader variability is a common limitation upon expert pathologists [26, 27].

Therefore, current recommendations extend the definition of the biopsy proven myocarditis to include immunohistochemical detection. The European Society of Cardiology further defines the histologic characteristic to include $\geq 14$ leucocytes $/ \mathrm{mm}^{2}$ including up to 4 monocytes $/ \mathrm{mm}^{2}$ with the presence of CD 3 positive T-lymphocytes $\geq 7 \mathrm{cells} / \mathrm{mm}^{2}$, [28]. Specific stains such as anti-CD3 (T lymphocytes), anti-CD68 (macrophages), and class I and II human leukocyte antigens, increase the sensitivity of the biopsy, as they detect small infiltrates missed by hematoxylin-eosin stain.

Given the variable yield from endomyocardial biopsy, and the recognition that endomyocardial biopsy is an invasive procedure with low but finites risks, a probabilistic approach has been advocated. Definitions that rely on clinical syndromes, biomarkers, and/or imaging abnormalities have been introduced and are clinically used to tailor further definitive evaluation as needed [29]. In low-risk patients, a diagnosis of "clinically suspected myocarditis" on the basis of clinical presentation and imaging diagnosis alone is accepted. This approach has been broadly employed during the SARS-CoV-2 pandemic, and while certainly understandable to reduce possible transmission during additional diagnostic testing, does reduce specificity.

In a 2013 European Society of Cardiology (ESC) position statement, a combination of clinical and cardiac imaging findings are used to inform clinical decision-making, though these findings are not diagnostic by themselves. "Clinically suspected" myocarditis is defined as having a clinical presentation of myocarditis and (1) diagnostic criteria if symptomatic (probable), or (2) diagnostic criteria if the patient is asymptomatic (possible) (Table 1) [28]. This global approach aligns with a step by step recommendations of major guidelines in the workup of myocarditis.

\section{CMR Criteria: Lake Louise Consensus Criteria (LLC) and Modified LCC Criteria}

The Lake Louise Consensus Criteria for cardiovascular magnetic resonance imaging (CMR) diagnosis of myocarditis is an expert consensus recommendation for patients with clinically suspected myocarditis [30] and defines CMR findings that are more likely consistent with myocarditis irrespective of the clinical presentation. The criteria require two out of the three categories to be present and those include: (1) evidence of myocardial edema with regional or global myocardial signal intensity increase in T2-weighted images, (2) early gadolinium enhancement suggestive of hyperemia and capillary leakage with an increased signal intensity ratio between myocardium and skeletal muscle in gadolinium-enhanced T1-weighted images, and/or (3) LGE in inversion recovery T1-weighted images with at least one focal lesion with nonischemic regional distribution (mainly subepicardium or mid-wall, and otherwise multifocal).

The diagnostic accuracy of the original LLC criteria ranges from $57-90 \%$ (average 84\%) with a sensitivity of $78 \%$ and specificity of $88 \%$ [31 $\bullet$. The criteria appear to be more accurate in the acute phase of the disease especially with an "infarct-like" presentation [32]. The course of myocardial inflammation limits the optimal sensitivity for diagnostic imaging to a few weeks from presentation [33]. Within this window, however, CMR can identify useful features, which may 
Table 1 Diagnostic Classification of Myocarditis and Application in SARS-CoV-2

Diagnostic classification

I. Definitive:

Criteria used

Biopsy

Dallas Criteria:

1- "inflammatory infiltrate of the myocardium with necrosis and/or degeneration of adjacent myocytes not typical of the ischemic damage associated with coronary artery disease"

2- Could be focal to diffuse, with lymphocytic, eosinophilic, granulomatous, giant cell, neutrophilic or mixed in nature with or without fibrosis

\# Borderline myocarditis is defined by an inflammatory infiltrate that appears sparse or when myocyte injury is not demonstrated

Immuno-histologic Criteria:

1- ESC endorsed : inflammatory infiltrate cutoff of $\geq 14$ leukocytes $/ \mathrm{mm}^{2}$, including up to 4 monocytes $/ \mathrm{mm}^{2}$, with the presence of CD3-positive T-lymphocytes $\geq 7$ cells $/ \mathrm{mm}^{2}$

2- anti-CD3 (T lymphocytes), anti-CD68 (macrophages), and class I and II human leukocyte antigens stains

1- Center specific approach: specific cardiac autoantibody detection (AntiANT, Anti-BCKD-E2)

II. Clinically suspected:

A. Probable

No biopsy

Clinical symptoms with at least one of the following:

1- Elevated biomarkers of cardiac injury

2- ECG findings of cardiac injury

3- Abnormal cardiac function on Echo or CMR

B. Possible

Absence of clinical symptoms with at least one of the following:

1- Elevated biomarkers of cardiac injury

2- ECG findings of cardiac injury

3- Abnormal cardiac function on Echo or CMR

European Society of Cardiology Position Statement Definition of Clinical Presentation and Diagnostic Measures [28]

Clinical Presentation

1. Acute chest pain, pleuritic, or pseudo-ischemic

2. New-onset ( $<3$ months) or worsening of: dyspnea at rest or exercise, and/or fatigue, with or without left and/or right heart failure signs

3. Subacute/chronic ( $>3$ months) or worsening of: dyspnea at rest or exercise, and/or fatigue, with or without left and/or right heart failure signs

4. Palpitation, and/or unexplained arrhythmia symptoms and/or syncope, and/or aborted sudden cardiac death

5. Unexplained cardiogenic shock
Diagnostic Criteria

1. Newly abnormal 12 lead ECG and/or Holter and/or stress testing

2. Elevated markers $(\mathrm{TnT} / \mathrm{TnI})$

3. Cardiac imaging: New, otherwise unexplained LV and/or RV structure and/or function abnormality

4. Tissue characterization by CMR: Edema and/or LGE of classical myocardial pattern also predict outcome independent of clinical symptoms [34-36]. For example, myocardial edema without LGE on CMR has been associated with improved recovery and outcomes [36]. Advances in T1, ECV and T2 mapping techniques have recently facilitated the incorporation of mapping quantification in a modified LLC version (Fig. 1). Inflamed myocardium typically exhibits higher T1, T2, and extracellular volume ECV values in the acute setting. The diagnostic accuracy of T1 and T2 mapping are estimated at 89 and $80 \%$ respectively [31••], although these are reduced in chronic settings and depend on the patient population studied [33]. However, T2 mapping has been suggested to be more specific for inflammation and may persist in the subacute phase [33]. There are also data to suggest that T2 mapping may help distinguish between active versus healed myocarditis [37], with an improved negative predictive value for inflammation
[38]. In acute myocarditis, a combined approach using native T1 mapping and LGE assessment seems to have superior diagnostic accuracy to LLC Criteria [39, 40].

In summary, except for a subset of the most critically ill patients with COVID-19, myocarditis is understandably diagnosed on clinical grounds without endomyocardial biopsy. Given the lack of specificity of imaging findings, SARSCoV2 myocarditis should be considered in the context of a clinical presentation compatible with myocarditis emphasizing symptoms, elevated cardiac markers and abnormal electrocardiograms. In this clinical context, imaging findings confirm the diagnosis and should include more than an isolated abnormality. For example, CMR findings should combine a T1 based and a T2 based abnormality or include supportive evidence such as pericarditis or regional or global left ventricular systolic dysfunction. Importantly, the diagnosis of SARS- 
Modified Lake Louise Criteria in SARS-CoV2 Myocarditis *

\section{T1 based imaging (Non-ischemic injury)}

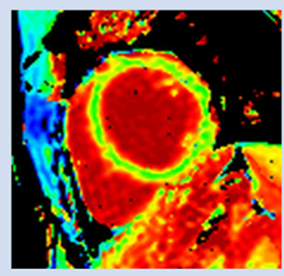

T1 map

\section{T2 based imaging} (Edema)

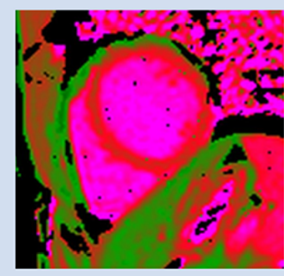

ECV

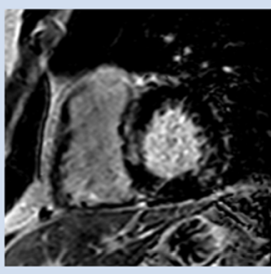

LGE

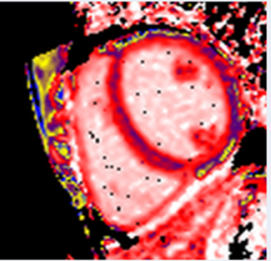

T2 map

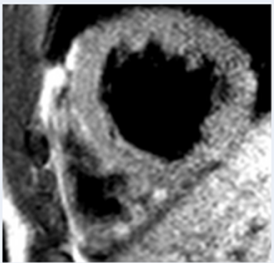

T2 TSE SA

\section{Supportive evidence: Pericarditis or LV dysfunction}

Fig. 1 Overview of the Modified Lake Louise Criteria (LLC) applied in SARS-CoV-2 Myocarditis. CMR imaging in patients with a clinical presentation of myocarditis* supports the diagnosis of acute myocardial inflammation if at least 1 criterion in each of the 2 categories is positive. $\mathrm{ECV}=$ extracellular volume; $\mathrm{LGE}=$ late gadolinium enhancement; $\mathrm{T} 2$
TSE $=$ T2-weighted Turbo spin echo sequence depicting T2-weighted image example. ${ }^{*}$ The clinical presentation includes concerning symptoms with elevated cardiac markers or electrocardiographic abnormalities, and SARS-CoV2 myocarditis should not be diagnosed outside of this clinical context based on isolated imaging findings
CoV2 myocarditis based on imaging findings alone should be avoided given unclear implications and lack of validation in other viral infections.

\section{Mechanisms of Viral Myocyte Injury}

To date, more than 20 viruses are known to cause myocarditis [41]. The dynamics of the different viruses and mechanisms of entry and replication, as well as the immune system response triggered, define the patient specific presentations. Clinically, this presentation may be expressed as a spectrum defined by the host/virus characteristics. For example, Coxsackievirus induced injury is specifically directed to myocardial cells. Conversely, Parvovirus B19 infect other cells in the heart, such as endothelial cells, and are typically not found in the myocytes. In most cases of infection, the virus is cleared by the immune system, though some patients may develop an immune reaction to endogenous antigens and suffer from prolonged cardiac dysfunction with or without acute inflammation [42]. A heightened immune response within the acute phase may lead to extensive or fulminant injury within the heart, while a chronic indolent infection may manifest as gradual remodeling leading to a dilated cardiomyopathy (DCM). Viral genomes within the cells may persist and may also be linked to cardiac remodeling. For example, persistence of the enteroviral genome has been implicated in the ongoing remodeling that occurs with some cases of DCM [43].

\section{Prognostic Variables in Myocarditis}

Predictors of outcome in patients with myocarditis encompass clinical presentation variables as well as immunohistochemical and imaging findings. Patients with acute coronary syndrome-like presentation and normal left ventricular ejection fraction (LVEF) have better outcomes than those with low LVEF [44]. In a study of 181 consecutive patients with clinically suspected viral myocarditis with endomyocardial biopsies, advanced New York Heart Association functional class was a predictor of poor outcome [5]. In pediatric patients with acute DCM, a reduced right ventricular (RV) function and a higher pulmonary artery pressures were associated with increased risk of death or need for cardiac transplantation $[45,46]$. Patients who present with complicated acute myocarditis defined by reduced LVEF $(<50 \%)$, sustained ventricular arrhythmias or need for inotropes or mechanical circulatory support are also at higher risk for death or transplant [47].

Associations with adverse outcome in active or borderline myocarditis defined by the Dallas Criteria 
depends on other clinical presentations such as severity of left ventricular or biventricular dysfunction [4]. The use of immunohistochemical techniques sheds light on the outcome of these patients, independent of the clinical presentation. For example, detection of specific autoantibodies (such as anti-alpha myosin autoantibodies) may be associated with progression to DCM [48-50], whereas higher titers of $\operatorname{IgG}$ were associated with better left ventricular function in the Myocarditis Treatment Trial [27]. Prognosis also appears to be worse with acute lymphocytic, eosinophilic, or Giant Cell myocarditis [51]. Of note, fulminant lymphocytic infiltrative myocarditis have been observed to have better outcomes even though patients may need inotropic or circulatory support as a bridge to recovery [51].

The importance of viral genome persistence as a predictor of outcome has been highlighted by a few studies and seems to be associated with improved LV function [52]. However, these findings may be virus-specific and not generalizable. Unlike genome persistence of enterovirus infection, patients with parvovirus B19 viral persistence within the myocardium do not demonstrate an association with death or heart transplant [5].

CMR has emerged as an indispensable tool to diagnose and predict outcome in patients with myocarditis. Extrapolating from prior echo studies, biventricular dysfunction detected on MRI in myocarditis is associated with death and transplantation [4]. Recently, studies have shown clinical association between CMR-late gadolinium enhancement (LGE) and subsequent arrhythmic events [35]. Moreover, LGE and its persistence over three months in patients with acute myocarditis has been linked to worse outcome [53,54]. In the acute phase, patchy, mid-wall, septal or inferior segment enhancement, and percentage of LG enhancement on CMR have been associated with adverse cardiac events [55].

\section{Therapies in Myocarditis}

In general, the management of patients with myocarditis follows the recommendation of treatment for patients with heart failure and arrhythmias. In heart failure with reduced ejection fraction, diuresis, and early initiation of Angiotensin Converting Enzyme (ACE) inhibitor or Angiotensin Receptor Blocker (ARB) is recommended in addition to beta blockers. Even though these recommendations are based on heart failure guidelines, murine models of viral myocarditis have shown benefit when ACE inhibitors and nonselective beta blocker are used $[56,57]$. Refractory heart failure and hemodynamic instability may necessitate advanced therapies such as mechanical circulatory support or transplantation.

\section{Virus-Directed Therapies}

\begin{abstract}
Although aggressive neuraminidase inhibitor use during the H1N1pfm2009 pandemic has been suggested to account for a lower case fatality rate in Japan [58], antiviral therapy in patients with lymphocytic myocarditis has not proven efficacious in humans [59]. Murine models of myocarditis due to Coxsackievirus B3 have been shown to respond to ribavirin or interferon alfa treatment. However this response is only seen with early or pre-infection therapy [60-62], and this narrow window for efficacy in those drugs may explain their uncertain benefit in humans.
\end{abstract}

\section{Immunosuppressive Therapies}

Anti-heart autoantibodies have been implicated in myocarditis and may explain autoimmune perpetuation of disease [63]. As such, multiple studies have targeted immune modulating therapies. However, variable animal model responses have been observed dependent on the virus, the animal model, specific treatment, and timing of the therapy [64-66]. To date, evidence supporting the use of immunosuppressive therapy in acute myocarditis of unspecified etiology is sparse. In the Myocarditis Treatment Trial, no difference in outcome was observed in patients with a histopathologic diagnosis of myocarditis of unspecified etiology and reduced LVEF $(<45 \%)$ who were randomized to conventional therapy or immunosuppression with either cyclosporine or azathioprine for 28 weeks [27]. Moreover, the true response to therapy is confounded by the high rate of spontaneous recovery in those patients with acute myocarditis. Yet, there are data to suggest clinical response to immunomodulatory therapy in chronic cases not responsive to conventional therapy. In two trials of patients with inflammatory cardiomyopathy of more than 6 months, immunosuppressive therapy with steroids and azathioprine showed improvement in LVEF and clinical status [67, 68]. Finally, data on intravenous immunoglobulin (IVIG) therapy in the setting of myocarditis are limited [69].

\section{SARS-CoV-2 Myocarditis}

Cardiac injury, including myocarditis, has been identified as a complication of previously detected coronaviruses strains 
such as SARS-CoV-1 and Middle East respiratory syndrome coronavirus (MERS-CoV) [70, 71]. Around 10-35\% of patients hospitalized with COVID-19 present with acute cardiac injury defined as an elevated high-sensitivity troponin I or troponin $\mathrm{T}$ (above the 99th percentile upper reference range) $[13,14,72-74]$. In these patients, acute cardiac injury has also been described in the absence of pulmonary disease $[75,76]$. The mechanisms of acute cardiac injury include oxygen supply-demand mismatch, microvascular and endothelial dysfunction, stress cardiomyopathy, systemic inflammation and others. As noted, most of these patients would not meet diagnostic criteria for myocarditis. However, there are data to favor an inflammatory mechanism of the myocardial damage. For example, patients with elevated troponins have higher levels of inflammatory markers such as C-reactive protein (CRP) [73]. Moreover, patients with fulminant myocarditis may respond rapidly with IVIG and steroid therapy [75, 77].

To date, multiple SARS-CoV-2 case reports have described findings consistent with a diagnosis of "clinically suspected myocarditis", though definite histologic confirmation is underreported [78-82]. In an autopsy cohort from Germany, SARS-CoV-2 cardiac infection was documented in $61.5 \%$ [83]. Among infected adults, detection of both SARS-CoV-2 RNA by RT-PCR and viral particles by electron microscopy in cardiac tissue has been reported in endomyocardial biopsy specimens [84]. Other data point to a tropic attraction of the virus to vascular pericytes and endothelial cells within the myocardium [85]. Patients with mild troponin elevation had scattered individual myocyte necrosis and CD4 and CD8 lymphocytes near vascular structures, whereas patients with more severe clinical presentations, such as fulminant myocarditis, had interstitial and perivascular inflammation with mainly CD68+ macrophages, and associated foci of cardiomyocyte necrosis [85•]. Macrophage involvement has also been seen with human pluripotent stem cell (PSC)-derived cardiomyocytes [86]. In another recently published international multicenter study, cardiac tissue from autopsies of 21 consecutive COVID-19 patients was assessed. Frequent macrophage infiltration was noted affecting $86 \%$ of the patients, while lymphocytic infiltration was present in only $14 \%$ of patients with varying $\mathrm{T}$ lymphocyte cells. The macrophage infiltration was seen to correlate with the elevated systemic levels of proinflammatory cytokines. In critical presentations, the virus seems to be detected more extensively affecting the capillary endothelial cells, endocardium endothelial cells, macrophages, neutrophils, and fibroblasts [85].

In addition, studies on induced PSC infected with SARSCoV-2 have suggested possible unusual mechanisms of myocyte injury without cellular apoptosis [87]. Even in the absence of actively replicating SARS-CoV-2 virus, myocyte damage occurs through altered transcription of genes involved in the contractile architecture of the myocyte. The authors suggest that these new findings are not detected by regular staining or standard immunohistochemical studies but do result in myocardial injury. This observation may explain why viral particles are not always detected within the myocardium, even when mild degree of infiltrating inflammatory cells are identified [88, 89]. Though more studies are needed to define the course of cellular damage present in SARS-CoV-2, the current variability in the description of myocarditis and viral genome detection in recent studies could be explained by these unusual mechanisms.

\section{SARS-CoV-2 and CMR}

As in other cases of viral myocarditis, CMR is used in SAR$\mathrm{CoV}-2$ infection to assess biventricular function, the pattern of edema and inflammation within the myocardium, and the presence of pericardial involvement. Of note, the available date are mostly retrospective with no pre-infection imaging. Moreover, apart from case reports, there are still little data on the acute CMR findings in patients with SARS-CoV-2 infection.

Studies to date show a spectrum of cardiac involvement by CMR. In 22 collegiate athletes with prior asymptomatic or at most mild SARS-CoV-2 infection, LGE was found in $9 \%$ of the cases with one meeting the modified LLC criteria for myocarditis [90]. In this study, CMR was performed at a median of 52 days after infection reducing the accuracy of the diagnostic criteria. Furthermore, without a pre-infection CMR, the true association of the LGE to the SARS-CoV-2 infection remains unclear.

In patients hospitalized in the UK with detected or presumed SARS-CoV-2 infection and elevated hsTnT not associated with a known pathology, 13/51 (25.5\%) screened patients had nonischemic or combined ischemic and nonischemic lesions identified on CMR [91]. In this cohort, no myocardial edema was noted, and $40 \%$ of those admitted to the intensive care unit had myocarditis-like features on CMR. In this study, the interval between symptom onset and CMR was an average of 46 days.

In a cohort of 100 patients recruited in Germany who recently recovered from SARS-CoV-2 infection including 33\% having severe disease requiring hospitalization, $20 \%$ exhibited a nonischemic LGE pattern after a median duration from positive testing of 71 days [92]. The most common abnormalities were elevated native $\mathrm{T} 1$ and $\mathrm{T} 2$ relaxation times $(73 \%$ and $60 \%$, respectively). Interestingly, 3 patients were referred for endomyocardial biopsy and results revealed active lymphocytic inflammation, a likely chronic persistent inflammatory process.

In symptomatic patients, case reports and cohort studies of patients undergoing CMR at the time of infection shed light on the findings associated with infection in more severe presentations. Probable myocarditis cases associated with elevated inflammatory markers attributed to SARS-CoV-2 infection 
have been documented and have shown typical CMR findings of LGE, increased T2 signal, and hypokinesia [89, 93-96]. The importance of the case reports is the time-sensitive documentation of the CMR findings during the acute phase of the infection. As discussed previously, CMR is understandably underutilized in probable myocarditis cases due to stringent precautions and risk/benefit judgment in mild versus severe cases.

Overall, the reported CMR findings, especially T1 and T2 relaxation times, vary between studies. These findings are not surprising as abnormalities may persist for 5 weeks or more [97]. Furthermore, certain limitations of the acquisitions of these sequences should be emphasized, including intervendor differences, absence of a universal standardized approach, the need for individual laboratory values to establish site-specific normal and abnormal ranges for parametric maps, and the sensitivity of the techniques for confounding diseases. A lack of appreciation of these limitations further complicates the understanding of the incidence on COVID-19 myocarditis.

\section{Prognosis and Treatment of SARS-CoV-2 Myocarditis}

In part because clinical and diagnostic variables of SARS-CoV-2 myocarditis and their relation to outcomes are not yet well defined, optimal management is also uncertain. In general, management follows similar recommendations for heart failure including pharmacological therapy, careful fluid management, and advanced therapies in cases of unresponsive or acute pump failure (Fig. 2). The speculations of ACE inhibitor cointeraction with the viral entry mechanism has not materialized in any study to-date and their use is still expected as part of the management of these patients, along with ARBs, angiotensin receptor neprolysin inhibitors, and mineralocorticoid receptor antagonists. Beyond standard guideline recommendations, anticoagulation prophylaxis or treatment is also controversial [98].

\section{SARS-CoV-2 Viral Directed Therapies}

Therapies for SARS-CoV-2 have focused primarily on respiratory function given that the predominant disease manifestation is pneumonia. Accordingly, there are little data to define therapeutic options in SARS-CoV-2 myocarditis. However, the trend for earlier intervention may also result in improved cardiovascular outcomes.

Remdesivir, a pro-drug which inhibits the viral RNA polymerase, has been approved for emergency use of patients with severe SARS-COV-2 infection. Even though in vitro studies have supported the use of this drug [99], clear clinical benefit for patients requiring oxygen supplementation is variable with little information yet on cardiovascular outcomes [20, 100, 101]. The WHO-sponsored SOLIDARITY trial did not show reduced 28-day mortality with Remdesivir treatment [102]. However, in the ACCT-1 study, a reduced mortality was seen only in patients requiring mild supplemental oxygen (less than high flow oxygen therapy) [20].

In vitro studies have demonstrated replication inhibition of the SARS-CoV-2 virus with interferon beta [103]. Moreover, recent studies have identified higher risk patients with genetic mutations of the interferon type I immunity cascade [104, 105]. Therefore, administration of recombinant interferons may represent a therapeutic opportunity to counterbalance a possible deficiency. Clinical results have again been variable with some studies suggesting improved outcome supporting the use of subcutaneous and inhaled interferon beta for symptomatic patients early in the disease $[106,107]$.

\section{Immunosuppressive Therapies}

Early data that supported the use of hydroxychloroquine and chloroquine in the pandemic originated in part from in vitro studies suggesting an inhibited cytokine response [108]. However, clinical benefit never materialized [109-111, $107 \cdot]$. In patients with myocardial injury, the data for immunosuppressive therapies, whether isolated or combined with respiratory disease, are limited. Among patients with COVID19 pneumonia, data from randomized trials support broad immunosuppression with glucocorticoids to reduce mortality in hypoxemic patients[112-114]. Targeted immune therapies have also been investigated, and in prior studies of patients with organ dysfunction and sepsis, subgroup analysis showed favorable outcome with IL-1 receptor antagonism $[115,116]$. A retrospective cohort study on patients with SARS-CoV-2 infection in Italy suggested that IL-1 antagonism, using anakinra, may be a therapeutic option [117]. Another casecontrol study on patients treated with $300 \mathrm{mg}$ of canakinumab demonstrated rapid reduction in the systemic inflammatory response and an improvement in oxygenation [118]. In a recently presented study published in patients with cardiac injury, patients treated with high dose canakinumab were numerically more likely to demonstrate clinical recovery at 28 days [119].

Several agents targeting IL-6, such as tocilizumab, sarilumab, and siltuximab, have also been evaluated in randomized trials as treatment for patients with COVID-19. Early observational results showed decreased risk of intubation or death. Unlike initial observational studies on tocilizumab $[120,121]$, patients with evidence of a pro-inflammatory state 


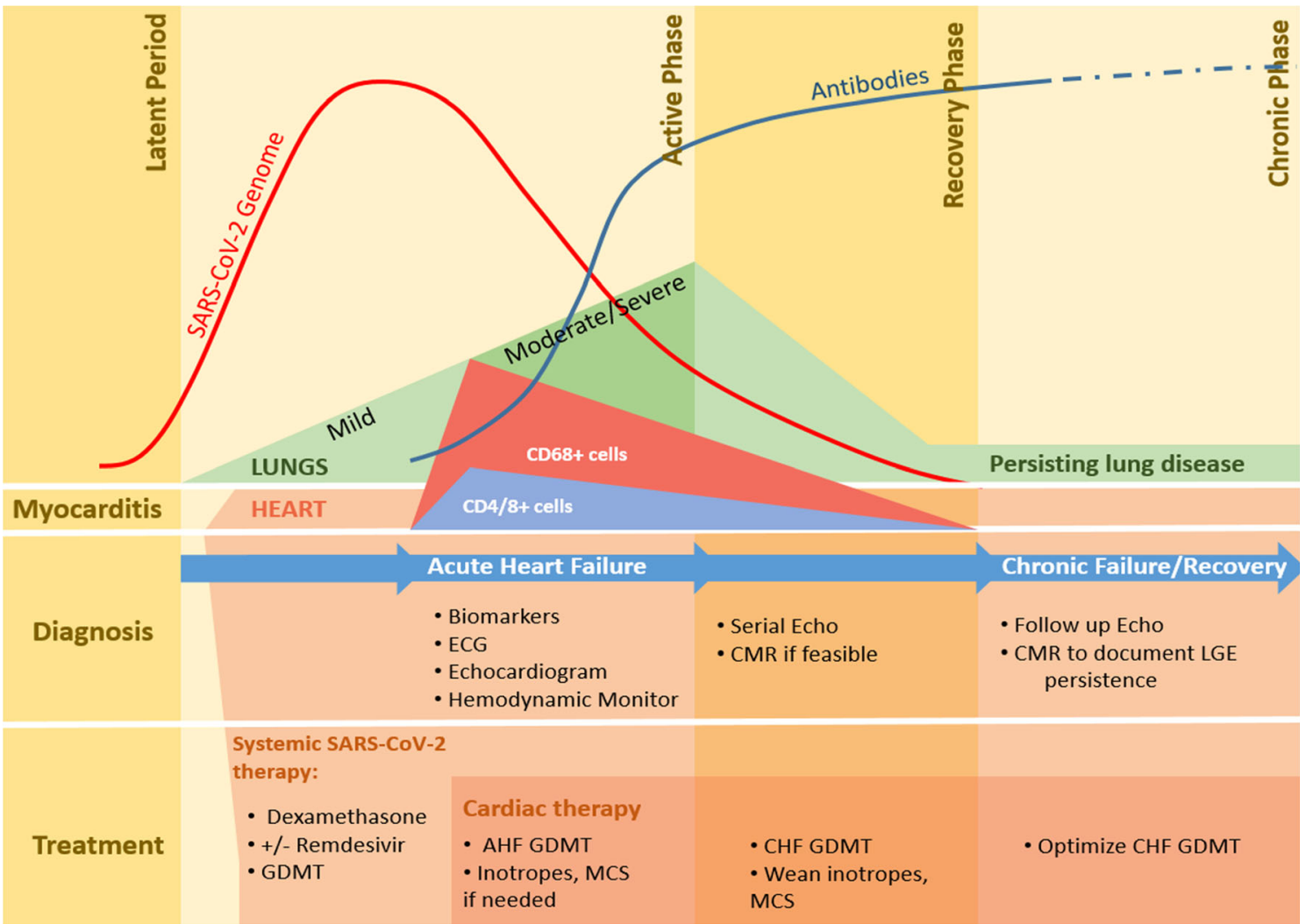

Fig. 2 Proposed illustration of clinical course and management, viral replication, and antibody detection in patients presenting with SARSCoV-2 associated myocarditis. Myocardial involvement with CD4/8+ lymphocytes and CD68+ Macrophage cells parallels the clinical presentation of cardiac dysfunction as depicted by elevated biomarkers, ECG, and echocardiographic abnormalities. In addition to systemic therapies currently approved for COVID-19, guideline directed

management of patients with acute heart failure is indicated including inotropes and mechanical circulatory support, if needed. Recovery and chronic phases post infection are managed according to guideline recommendations for chronic heart failure. GDMT = guideline directed therapy; $\mathrm{MCS}=$ Mechanical circulatory support; $\mathrm{AHF}=$ acute heart failure; $\mathrm{CHF}=$ chronic heart failure

did not show significant improvement with single dose treatment [122]. On the other hand, results from the REMAP-CAP study has shown improved outcomes for critically ill patients receiving tocilizumab and sarilumab [123]. As such, the use of those drugs may be limited to critically ill patients with a heightened inflammatory response.

Convalescent plasma is obtained from individuals who have previously contracted and recovered from COVID-19. The plasma contains neutralizing antibodies and provides passive immunity to patients who have not developed a humoral immune defense to the infection. The FDA has granted emergency use approval of convalescent plasma for hospitalized patients, although randomized trials have not demonstrated a clinical benefit [124-126].

In summary, data supporting specific therapies in SARS-CoV-2 myocarditis are lacking. In the setting of concomitant pneumonia, dexamethasone in hypoxemic patients and IL-6 antagonists in severely ill patients with a marked systemic inflammatory response are reasonable. In patients with isolated SARS-CoV-2 myocarditis who are hospitalized or hypoxemic, corticosteroids could be considered. However, corticosteroids should likely be avoided in patients with less severe illness. Regarding targeted immunomodulatory therapy with IL-1 or IL-6 antagonists, additional data are needed before use could be recommended specifically for SARSCoV2-myocarditis.

\section{Conclusion}

Acute myocardial injury in the setting of SARS-CoV-2 infection is common, and even though the exact incidence of myocarditis is unknown, this diagnosis is much less frequent. Our understanding of the incidence of SARS-CoV-2 myocarditis has been understandably limited due to a reliance on clinical criteria and variation in the diagnostic work-up. CMR is invaluable in this evaluation, yet the cross-sectional design of studies, inconsistencies in CMR protocols, and limited correlation with histological findings has provided an incomplete picture. Yet, in some patients, cardiac involvement does seem to persist beyond the acute presentation, but clinical 
consequences are unclear. Importantly, SARS-CoV2 myocarditis should be diagnosed within an appropriate clinical context and should not be based on isolated CMR findings, as the implications of indiscriminate imaging following a viral infection are unclear. Currently, management of SARS-CoV-2 myocarditis follows standard heart failure guidelines. However, earlier treatment directed at respiratory symptoms with the goal of promoting viral clearance may have an additional benefit of reducing subsequent cardiovascular complications. Once myocarditis has become manifest, immunosuppression may be indicated, especially in hospitalized patients with hypoxemia and increased systemic inflammation, although data to support this approach are currently lacking. Overall, our understanding of SARS-CoV-2 myocarditis would benefit from standardized diagnostic testing and controlled studies of potential efficacious therapies.

\section{Declarations}

Human and Animal Rights and Informed Consent This article does not contain any studies with human or animal subjects performed by any of the authors.

Conflict of Interest Dr. Wang reports grants from National Heart Foundation of New Zealand, outside the submitted work.

Dr. Cremer reports grants from Novartis Pharmaceuticals and Kiniksa Pharmaceuticals; and personal fees from Kiniksa Pharmaceuticals and Sobi Pharmaceuticals, outside the submitted work.

The other authors declare that they have no conflict of interest.

\section{References}

Papers of particular interest, published recently, have been highlighted as:

- Of importance

- Of major importance

1. Huber SA, Gauntt CJ, Sakkinen P. Enteroviruses and myocarditis: viral pathogenesis through replication, cytokine induction, and immunopathogenicity. Adv Virus Res [Internet]. 1998;51:35-80 Available from: http://www.ncbi.nlm.nih.gov/pubmed/9891585.

2. Klingel K, Hohenadl C, Canu A, Albrecht M, Seemann M, Mall $\mathrm{G}$, et al. Ongoing enterovirus-induced myocarditis is associated with persistent heart muscle infection: quantitative analysis of virus replication, tissue damage, and inflammation. Proc Natl Acad Sci U S A [Internet]. 1992;89:314-8 Available from: http://www. ncbi.nlm.nih.gov/pubmed/1309611.

3. Malkiel S, Kuan AP, Diamond B. Autoimmunity in heart disease: mechanisms and genetic susceptibility. Mol Med Today [Internet]. 1996;2:336-42 Available from: http://www.ncbi.nlm. nih.gov/pubmed/8796919.

4. Caforio ALP, Calabrese F, Angelini A, Tona F, Vinci A, Bottaro $\mathrm{S}$, et al. A prospective study of biopsy-proven myocarditis: prognostic relevance of clinical and aetiopathogenetic features at diagnosis. Eur Heart J [Internet]. 2007;28:1326-33 Available from: http://www.ncbi.nlm.nih.gov/pubmed/17493945.

5. Kindermann I, Kindermann M, Kandolf R, Klingel K, Bültmann B, Müller T, et al. Predictors of outcome in patients with suspected myocarditis. Circulation [Internet]. 2008;118:639-48 Available from: http://www.ncbi.nlm.nih.gov/pubmed/18645053.

6. Mahrholdt H, Goedecke C, Wagner A, Meinhardt G, Athanasiadis A, Vogelsberg H, et al. Cardiovascular magnetic resonance assessment of human myocarditis: a comparison to histology and molecular pathology. Circulation [Internet]. 2004;109:1250-8 Available from: http://www.ncbi.nlm.nih.gov/pubmed/14993139.

7. Bock C-T, Klingel K, Kandolf R. Human parvovirus B19associated myocarditis. N Engl J Med [Internet]. 2010;362: 1248-9 Available from: http://www.ncbi.nlm.nih.gov/pubmed/ 20357294.

8. Baboonian C, Treasure T. Meta-analysis of the association of enteroviruses with human heart disease. Heart Int. 1997;78:539-43 Available from: http://www.ncbi.nlm.nih.gov/pubmed/9470867.

9. Maisch B, Schönian U, Crombach M, Wendl I, Bethge C, Herzum $\mathrm{M}$, et al. Cytomegalovirus associated inflammatory heart muscle disease. Scand J Infect Dis Suppl [Internet]. 1993;88:135-48 Available from: http://www.ncbi.nlm.nih.gov/pubmed/8390717.

10. Kühl U, Pauschinger M, Noutsias M, Seeberg B, Bock T, Lassner $\mathrm{D}$, et al. High prevalence of viral genomes and multiple viral infections in the myocardium of adults with "idiopathic" left ventricular dysfunction. Circulation [Internet]. 2005;111:887-93 Available from: http://www.ncbi.nlm.nih.gov/pubmed/15699250.

11. Alexander LK, Keene BW, Small JD, Yount B, Baric RS. Electrocardiographic changes following rabbit coronavirusinduced myocarditis and dilated cardiomyopathy. Adv Exp Med Biol [Internet]. 1993;342:365-70 Available from: http://www. ncbi.nlm.nih.gov/pubmed/8209755.

12. CDC COVID-19 Response Team. Severe Outcomes Among Patients with Coronavirus Disease 2019 (COVID-19) - United States, February 12-March 16, 2020. MMWR Morb Mortal Wkly Rep [Internet]. 2020;69:343-6 Available from: http:// www.ncbi.nlm.nih.gov/pubmed/32214079.

13. Shi S, Qin M, Shen B, Cai Y, Liu T, Yang F, et al. Association of Cardiac Injury With Mortality in Hospitalized Patients With COVID-19 in Wuhan, China. JAMA Cardiol [Internet]. 2020;5: 802-10 Available from: http://www.ncbi.nlm.nih.gov/pubmed/ 32211816.

14. Guo T, Fan Y, Chen M, Wu X, Zhang L, He T, et al. Cardiovascular Implications of Fatal Outcomes of Patients With Coronavirus Disease 2019 (COVID-19). JAMA Cardiol [Internet]. 2020;5:811-8 Available from: http://www.ncbi.nlm. nih.gov/pubmed/32219356.

15. Atri D, Siddiqi HK, Lang JP, Nauffal V, Morrow DA, Bohula EA. COVID-19 for the Cardiologist: Basic Virology, Epidemiology, Cardiac Manifestations, and Potential Therapeutic Strategies. JACC Basic to Transl Sci [Internet]. 2020;5:518-36 Available from: http:/www.ncbi.nlm.nih.gov/pubmed/32292848.

16. Akhmerov A, Marbán E. COVID-19 and the Heart. Circ Res [Internet]. 2020;126:1443-55 Available from: http://www.ncbi. nlm.nih.gov/pubmed/32252591.

17. Pericàs JM, Hernandez-Meneses $\mathrm{M}$, Sheahan TP, Quintana $\mathrm{E}$, Ambrosioni J, Sandoval E, et al. COVID-19: from epidemiology to treatment. Eur Heart J [Internet]. 2020;41:2092-112 Available from: http://www.ncbi.nlm.nih.gov/pubmed/32511724.

18. Tersalvi G, Vicenzi M, Calabretta D, Biasco L, Pedrazzini G, Winterton D. Elevated Troponin in Patients With Coronavirus Disease 2019: Possible Mechanisms. J Card Fail [Internet]. 
2020;26:470-5 Available from: http://www.ncbi.nlm.nih.gov/ pubmed/32315733.

19. RECOVERY Collaborative Group, Horby P, Lim WS, Emberson JR, Mafham M, Bell JL, et al. Dexamethasone in Hospitalized Patients with Covid-19 - Preliminary Report. N Engl J Med [Internet]. 2020; Available from: http://www.ncbi.nlm.nih.gov/ pubmed/32678530.

20. Beigel JH, Tomashek KM, Dodd LE, Mehta AK, Zingman BS, Kalil AC, et al. Remdesivir for the Treatment of Covid-19 - Final Report. N Engl J Med [Internet]. 2020;383:1813-26 Available from: http://www.ncbi.nlm.nih.gov/pubmed/32445440.

21. Richardson P, McKenna W, Bristow M, Maisch B, Mautner B, O'Connell J, et al. Report of the 1995 World Health Organization/ International Society and Federation of Cardiology Task Force on the Definition and Classification of cardiomyopathies. Circulation [Internet]. 1996;93:841-2 Available from: http://www.ncbi.nlm. nih.gov/pubmed/8598070.

22. Aretz HT, Billingham ME, Edwards WD, Factor SM, Fallon JT, Fenoglio JJ, et al. Myocarditis. A histopathologic definition and classification. Am J Cardiovasc Pathol [Internet]. 1987;1:3-14 Available from: http://www.ncbi.nlm.nih.gov/pubmed/3455232.

23. Hauck AJ, Kearney DL, Edwards WD. Evaluation of postmortem endomyocardial biopsy specimens from 38 patients with lymphocytic myocarditis: implications for role of sampling error. Mayo Clin Proc [Internet]. 1989;64:1235-45 Available from: http:// www.ncbi.nlm.nih.gov/pubmed/2593714.

24. Chow LH, Radio SJ, Sears TD, McManus BM. Insensitivity of right ventricular endomyocardial biopsy in the diagnosis of myocarditis. J Am Coll Cardiol [Internet]. 1989;14:915-20 Available from: http://www.ncbi.nlm.nih.gov/pubmed/2794278.

25. Wu LA, Lapeyre AC, Cooper LT. Current role of endomyocardial biopsy in the management of dilated cardiomyopathy and myocarditis. Mayo Clin Proc [Internet]. 2001;76:1030-8 Available from: http://www.ncbi.nlm.nih.gov/pubmed/11605687.

26. Baughman KL. Diagnosis of myocarditis: death of Dallas criteria. Circulation [Internet]. 2006;113:593-5 Available from: http:// www.ncbi.nlm.nih.gov/pubmed/16449736.

27. Mason JW, O'Connell JB, Herskowitz A, Rose NR, McManus $\mathrm{BM}$, Billingham ME, et al. A clinical trial of immunosuppressive therapy for myocarditis. The Myocarditis Treatment Trial Investigators. N Eng1 J Med [Internet]. 1995;333:269-75 Available from: http://www.ncbi.nlm.nih.gov/pubmed/7596370.

28. Caforio ALP, Pankuweit S, Arbustini E, Basso C, Gimeno-Blanes J, Felix SB, et al. Current state of knowledge on aetiology, diagnosis, management, and therapy of myocarditis: a position statement of the European Society of Cardiology Working Group on Myocardial and Pericardial Diseases. Eur Heart J [Internet]. 2013;34:2636-48 2648a-2648d. Available from: http://www. ncbi.nlm.nih.gov/pubmed/23824828.

29. Sagar S, Liu PP, Cooper LT. Myocarditis. Lancet (London, England) [Internet]. 2012;379:738-47 Available from: http:// www.ncbi.nlm.nih.gov/pubmed/22185868.

30. Friedrich MG, Sechtem U, Schulz-Menger J, Holmvang G, Alakija P, Cooper LT, et al. Cardiovascular magnetic resonance in myocarditis: A a JACC White Paper. J Am Coll Cardiol [Internet]. 2009;53:1475-87 Available from: http://www.ncbi. nlm.nih.gov/pubmed/19389557.

31.• Ferreira VM, Schulz-Menger J, Holmvang G, Kramer CM, Carbone I, Sechtem U, et al. Cardiovascular Magnetic Resonance in Nonischemic Myocardial Inflammation: Expert Recommendations. J Am Coll Cardiol [Internet]. 2018;72:315876 Available from: http://www.ncbi.nlm.nih.gov/pubmed/ 30545455. Advances in CMR criteria for documenting myocarditis helps standardize the diagnosis of patients presenting with SARS-CoV-2 myocarditis.

32. Lurz P, Eitel I, Adam J, Steiner J, Grothoff M, Desch S, et al. Diagnostic performance of CMR imaging compared with EMB in patients with suspected myocarditis. JACC Cardiovasc Imaging [Internet]. 2012;5:513-24 Available from: http://www.ncbi.nlm. nih.gov/pubmed/22595159.

33. Lurz P, Luecke C, Eitel I, Föhrenbach F, Frank C, Grothoff M, et al. Comprehensive Cardiac Magnetic Resonance Imaging in Patients With Suspected Myocarditis: The MyoRacer-Trial. J Am Coll Cardiol [Internet]. 2016;67:1800-11 Available from: http://www.ncbi.nlm.nih.gov/pubmed/27081020.

34. Schumm J, Greulich S, Wagner A, Grün S, Ong P, Bentz K, et al. Cardiovascular magnetic resonance risk stratification in patients with clinically suspected myocarditis. J Cardiovasc Magn Reson [Internet]. 2014;(16):14 Available from: http://www.ncbi.nlm.nih. gov/pubmed/24461053.

35. Kadkhodayan A, Chareonthaitawee P, Raman SV, Cooper LT. Imaging of Inflammation in Unexplained Cardiomyopathy. JACC Cardiovasc Imaging [Internet]. 2016;9:603-17 Available from: http://www.ncbi.nlm.nih.gov/pubmed/27151523.

36. Vermes E, Childs H, Faris P, Friedrich MG. Predictive value of CMR criteria for LV functional improvement in patients with acute myocarditis. Eur Heart J Cardiovasc Imaging [Internet]. 2014;15:1140-4 Available from: http://www.ncbi.nlm.nih.gov/ pubmed/24925145.

37. Bohnen S, Radunski UK, Lund GK, Tahir E, Avanesov M, Stehning C, et al. T1 mapping cardiovascular magnetic resonance imaging to detect myocarditis-Impact of slice orientation on the diagnostic performance. Eur J Radiol [Internet]. 2017;86:6-12 Available from: http://www.ncbi.nlm.nih.gov/pubmed/28027767.

38. von Knobelsdorff-Brenkenhoff F, Schüler J, Dogangüzel S, Dieringer MA, Rudolph A, Greiser A, et al. Detection and Monitoring of Acute Myocarditis Applying Quantitative Cardiovascular Magnetic Resonance. Circ Cardiovasc Imaging [Internet]. 2017;10:e05242 Available from: http://www.ncbi. nlm.nih.gov/pubmed/28213448.

39. Kotanidis CP, Bazmpani M-A, Haidich A-B, Karvounis C, Antoniades C, Karamitsos TD. Diagnostic Accuracy of Cardiovascular Magnetic Resonance in Acute Myocarditis: A Systematic Review and Meta-Analysis. JACC Cardiovasc Imaging [Internet]. 2018;11:1583-90 Available from: http:// www.ncbi.nlm.nih.gov/pubmed/29454761.

40. Pan JA, Lee YJ, Salerno M. Diagnostic Performance of Extracellular Volume, Native T1, and T2 Mapping Versus Lake Louise Criteria by Cardiac Magnetic Resonance for Detection of Acute Myocarditis: A Meta-Analysis. Circ Cardiovasc Imaging [Internet]. 2018;11:e007598 Available from: http://www.ncbi. nlm.nih.gov/pubmed/30012826.

41. Schultheiss H-P, Kühl U, Cooper LT. The management of myocarditis. Eur Heart J [Internet]. 2011;32:2616-25 Available from: http://www.ncbi.nlm.nih.gov/pubmed/21705357.

42. Knowlton KU. CVB infection and mechanisms of viral cardiomyopathy. Curr Top Microbiol Immunol [Internet]. 2008;323:31535 Available from: http://www.ncbi.nlm.nih.gov/pubmed/ 18357777.

43. Wessely R, Klingel K, Santana LF, Dalton N, Hongo M, Jonathan Lederer $\mathrm{W}$, et al. Transgenic expression of replication-restricted enteroviral genomes in heart muscle induces defective excitationcontraction coupling and dilated cardiomyopathy. J Clin Invest [Internet]. 1998;102:1444-53 Available from: http://www.ncbi. nlm.nih.gov/pubmed/9769337. 
44. Imazio M, Brucato A, Barbieri A, Ferroni F, Maestroni S, Ligabue $\mathrm{G}$, et al. Good prognosis for pericarditis with and without myocardial involvement: results from a multicenter, prospective cohort study. Circulation [Internet]. 2013;128:42-9 Available from: http://www.ncbi.nlm.nih.gov/pubmed/23709669.

45. Foerster SR, Canter CE, Cinar A, Sleeper LA, Webber SA, Pahl E, et al. Ventricular remodeling and survival are more favorable for myocarditis than for idiopathic dilated cardiomyopathy in childhood: an outcomes study from the Pediatric Cardiomyopathy Registry. Circ Heart Fail [Internet]. 2010;3:689-97 Available from: http://www.ncbi.nlm.nih.gov/pubmed/20833772.

46. Alvarez JA, Orav EJ, Wilkinson JD, Fleming LE, Lee DJ, Sleeper LA, et al. Competing risks for death and cardiac transplantation in children with dilated cardiomyopathy: results from the pediatric cardiomyopathy registry. Circulation [Internet]. 2011;124:814-23 Available from: http://www.ncbi.nlm.nih.gov/pubmed/21788591.

47. Ammirati E, Cipriani M, Moro C, Raineri C, Pini D, Sormani P, et al. Clinical Presentation and Outcome in a Contemporary Cohort of Patients With Acute Myocarditis: Multicenter Lombardy Registry. Circulation [Internet]. 2018;138:1088-99 Available from: http://www.ncbi.nlm.nih.gov/pubmed/29764898.

48. Caforio AL, Goldman JH, Haven AJ, Baig KM, Libera LD, McKenna WJ. Circulating cardiac-specific autoantibodies as markers of autoimmunity in clinical and biopsy-proven myocarditis. The Myocarditis Treatment Trial Investigators. Eur Heart J [Internet]. 1997;18:270-5 Available from: http://www.ncbi.nlm. nih.gov/pubmed/9043844.

49. Lauer B, Schannwell M, Kühl U, Strauer BE, Schultheiss HP. Antimyosin autoantibodies are associated with deterioration of systolic and diastolic left ventricular function in patients with chronic myocarditis. J Am Coll Cardiol [Internet]. 2000;35:11-8 Available from: http://www.ncbi.nlm.nih.gov/pubmed/10636253.

50. Caforio ALP, Vinci A, Iliceto S. Anti-heart autoantibodies in familial dilated cardiomyopathy. Autoimmunity [Internet]. 2008;41: 462-9 Available from: http://www.ncbi.nlm.nih.gov/pubmed/ 18781472.

51. Cooper LT. Myocarditis. N Engl J Med [Internet]. 2009;360: 1526-38 Available from: http://www.ncbi.nlm.nih.gov/pubmed/ 19357408.

52. Kühl U, Pauschinger M, Seeberg B, Lassner D, Noutsias M, Poller $\mathrm{W}$, et al. Viral persistence in the myocardium is associated with progressive cardiac dysfunction. Circulation [Internet]. 2005;112: 1965-70 Available from: http://www.ncbi.nlm.nih.gov/pubmed/ 16172268.

53. Grün S, Schumm J, Greulich S, Wagner A, Schneider S, Bruder O, et al. Long-term follow-up of biopsy-proven viral myocarditis: predictors of mortality and incomplete recovery. J Am Coll Cardiol [Internet]. 2012;59:1604-15 Available from: http:// www.ncbi.nlm.nih.gov/pubmed/22365425.

54. Barone-Rochette G, Augier C, Rodière M, Quesada J-L, Foote A, Bouvaist $\mathrm{H}$, et al. Potentially simple score of late gadolinium enhancement cardiac MR in acute myocarditis outcome. J Magn Reson Imaging [Internet]. 2014;40:1347-54 Available from: http://www.ncbi.nlm.nih.gov/pubmed/24293405.

55. Gräni C, Eichhorn C, Bière L, Murthy VL, Agarwal V, Kaneko K, et al. Prognostic Value of Cardiac Magnetic Resonance Tissue Characterization in Risk Stratifying Patients With Suspected Myocarditis. J Am Coll Cardiol [Internet]. 2017;70:1964-76 Available from: http://www.ncbi.nlm.nih.gov/pubmed/29025553.

56. Rezkalla S, Kloner RA, Khatib G, Khatib R. Effect of delayed captopril therapy on left ventricular mass and myonecrosis during acute coxsackievirus murine myocarditis. Am Heart J [Internet].
1990;120:1377-81 Available from: http://www.ncbi.nlm.nih.gov/ pubmed/2174203.

57. Tominaga M, Matsumori A, Okada I, Yamada T, Kawai C. Betablocker treatment of dilated cardiomyopathy. Beneficial effect of carteolol in mice. Circulation [Internet]. 1991;83:2021-8 Available from: http://www.ncbi.nlm.nih.gov/pubmed/1674900.

58. Ukimura A, Satomi H, Ooi Y, Kanzaki Y. Myocarditis Associated with Influenza A H1N1pdm2009. Influenza Res Treat [Internet]. 2012;2012:351979 Available from: http://www.ncbi.nlm.nih.gov/ pubmed/23304476.

59. Rose NR, Neumann DA, Herskowitz A. Coxsackievirus myocarditis. Adv Intern Med [Internet]. 1992;37:411-29 Available from: http://www.ncbi.nlm.nih.gov/pubmed/1558005.

60. Kishimoto C, Crumpacker CS, Abelmann WH. Ribavirin treatment of murine coxsackievirus B3 myocarditis with analyses of lymphocyte subsets. J Am Coll Cardiol [Internet]. 1988;12:1334 41 Available from: http://www.ncbi.nlm.nih.gov/pubmed/ 2844874.

61. Kishimoto C, Crumpacker CS, Abelmann WH. Prevention of murine coxsackie B3 viral myocarditis and associated lymphoid organ atrophy with recombinant human leucocyte interferon alpha A/D, Cardiovasc Res [Internet]. 1988;22:732-8 Available from: http://www.ncbi.nlm.nih.gov/pubmed/2855719.

62. Matsumori A, Tomioka N, Kawai C. Protective effect of recombinant alpha interferon on coxsackievirus B3 myocarditis in mice. Am Heart J [Internet]. 1988;115:1229-32 Available from: http:// www.ncbi.nlm.nih.gov/pubmed/2837073.

63. Caforio ALP, Angelini A, Blank M, Shani A, Kivity S, Goddard $\mathrm{G}$, et al. Passive transfer of affinity-purified anti-heart autoantibodies (AHA) from sera of patients with myocarditis induces experimental myocarditis in mice. Int J Cardiol [Internet]. 2015;179: 166-77 Available from: http://www.ncbi.nlm.nih.gov/pubmed/ 25464438.

64. Padalko E, Verbeken E, Matthys P, Aerts JL, De Clercq E, Neyts J. Mycophenolate mofetil inhibits the development of Coxsackie B3-virus-induced myocarditis in mice. BMC Microbiol [Internet]. 2003;3:25 Available from: http://www.ncbi.nlm.nih.gov/pubmed/ 14687413.

65. Tomioka N, Kishimoto C, Matsumori A, Kawai C. Effects of prednisolone on acute viral myocarditis in mice. J Am Coll Cardiol [Internet]. 1986;7:868-72 Available from: http://www. ncbi.nlm.nih.gov/pubmed/3007597.

66. Monrad ES, Matsumori A, Murphy JC, Fox JG, Crumpacker CS, Abelmann WH. Therapy with cyclosporine in experimental murine myocarditis with encephalomyocarditis virus. Circulation [Internet]. 1986;73:1058-64 Available from: http://www.ncbi. nlm.nih.gov/pubmed/3698228.

67. London RS, Bradley L, Chiamori NY. Effect of a nutritional supplement on premenstrual symptomatology in women with premenstrual syndrome: a double-blind longitudinal study. J Am Coll Nutr [Internet]. 1991;10:494-9 Available from: http://www. ncbi.nlm.nih.gov/pubmed/1955626.

68. Wojnicz R, Nowalany-Kozielska E, Wojciechowska C, Glanowska G, Wilczewski P, Niklewski T, et al. Randomized, placebo-controlled study for immunosuppressive treatment of inflammatory dilated cardiomyopathy: two-year follow-up results. Circulation [Internet]. 2001;104:39-45 Available from: http:// www.ncbi.nlm.nih.gov/pubmed/11435335.

69. Robinson JL, Hartling L, Crumley E, Vandermeer B, Klassen TP. A systematic review of intravenous gamma globulin for therapy of acute myocarditis. BMC Cardiovasc Disord [Internet]. 2005;5:12 Available from: http://www.ncbi.nlm.nih.gov/pubmed/15932639. 
70. Yu C-M, Wong RS-M, Wu EB, Kong S-L, Wong J, Yip GW-K, et al. Cardiovascular complications of severe acute respiratory syndrome. Postgrad Med J [Internet]. 2006;82:140-4 Available from: http://www.ncbi.nlm.nih.gov/pubmed/16461478.

71. Alhogbani T. Acute myocarditis associated with novel Middle east respiratory syndrome coronavirus. Ann Saudi Med [Internet]. 2016;36:78-80 Available from: http://www.ncbi.nlm. nih.gov/pubmed/26922692.

72. Wang D, Hu B, Hu C, Zhu F, Liu X, Zhang J, et al. Clinical Characteristics of 138 Hospitalized Patients With 2019 Novel Coronavirus-Infected Pneumonia in Wuhan, China. JAMA [Internet]. 2020;323:1061-9 Available from: http://www.ncbi. nlm.nih.gov/pubmed/32031570.

73. Lala A, Johnson KW, Januzzi JL, Russak AJ, Paranjpe I, Richter F, et al. Prevalence and Impact of Myocardial Injury in Patients Hospitalized With COVID-19 Infection. J Am Coll Cardiol [Internet]. 2020;76:533-46 Available from: http://www.ncbi. nlm.nih.gov/pubmed/32517963.

74. Huang C, Wang Y, Li X, Ren L, Zhao J, Hu Y, et al. Clinical features of patients infected with 2019 novel coronavirus in Wuhan, China. Lancet (London, England) [Internet]. 2020;395: 497-506 Available from: http://www.ncbi.nlm.nih.gov/pubmed/ 31986264.

75. Irabien-Ortiz Á, Carreras-Mora J, Sionis A, Pàmies J, Montiel J, Tauron M. Fulminant myocarditis due to COVID-19. Rev Esp Cardiol (Engl Ed) [Internet]. 2020;73:503-4 Available from: http://www.ncbi.nlm.nih.gov/pubmed/32345547.

76. Paul J-F, Charles P, Richaud C, Caussin C, Diakov C. Myocarditis revealing COVID-19 infection in a young patient. Eur Heart J Cardiovasc Imaging [Internet]. 2020;21:776 Available from: http://www.ncbi.nlm.nih.gov/pubmed/32338706.

77. Lara D, Young T, Del Toro K, Chan V, Ianiro C, Hunt K, et al. Acute Fulminant Myocarditis in a Pediatric Patient With COVID19 Infection. Pediatr Int. 2020;146:e20201509 Available from: http://www.ncbi.nlm.nih.gov/pubmed/32747591.

78. Tavazzi G, Pellegrini C, Maurelli M, Belliato M, Sciutti F, Bottazzi A, et al. Myocardial localization of coronavirus in COVID-19 cardiogenic shock. Eur J Heart Fail [Internet]. 2020;22:911-5 Available from: http://www.ncbi.nlm.nih.gov/ pubmed/32275347.

79. Tian S, Xiong Y, Liu H, Niu L, Guo J, Liao M, et al. Pathological study of the 2019 novel coronavirus disease (COVID-19) through postmortem core biopsies. Mod Pathol [Internet]. 2020;33:100714 Available from: http://www.ncbi.nlm.nih.gov/pubmed/ 32291399.

80. Barton LM, Duval EJ, Stroberg E, Ghosh S, Mukhopadhyay S. COVID-19 Autopsies, Oklahoma, USA. Am J Clin Pathol [Internet]. 2020;153:725-33 Available from: http://www.ncbi. nlm.nih.gov/pubmed/32275742.

81. Varga Z, Flammer AJ, Steiger P, Haberecker M, Andermatt R, Zinkernagel AS, et al. Endothelial cell infection and endotheliitis in COVID-19. Lancet (London, England) [Internet]. 2020;395: 1417-8 Available from: http://www.ncbi.nlm.nih.gov/pubmed/ 32325026.

82. Xu Z, Shi L, Wang Y, Zhang J, Huang L, Zhang C, et al. Pathological findings of COVID-19 associated with acute respiratory distress syndrome. Lancet Respir Med [Internet]. 2020;8: 420-2 Available from: http://www.ncbi.nlm.nih.gov/pubmed/ 32085846 .

83. Lindner D, Fitzek A, Bräuninger H, Aleshcheva G, Edler C, Meissner K, et al. Association of Cardiac Infection With SARSCoV-2 in Confirmed COVID-19 Autopsy Cases. JAMA Cardiol
[Internet]. 2020;5:1281-5 Available from: http://www.ncbi.nlm. nih.gov/pubmed/32730555.

84. Escher F, Pietsch H, Aleshcheva G, Bock T, Baumeier C, Elsaesser A, et al. Detection of viral SARS-CoV-2 genomes and histopathological changes in endomyocardial biopsies. ESC Hear Fail [Internet]. 2020;7:2440-7 Available from: http://www.ncbi. nlm.nih.gov/pubmed/32529795.

85. Fox SE, Li G, Akmatbekov A, Harbert JL, Lameira FS, Brown JQ, et al. Unexpected Features of Cardiac Pathology in COVID19 Infection. Circulation [Internet]. 2020;142:1123-5 Available from: http://www.ncbi.nlm.nih.gov/pubmed/32689809. SARSCoV-2 tropism to cardiac pericytes and endothelial cells has been documented further supporting myocardial injury in patients presenting with myocarditis picture.

86. Chen S, Yang L, Nilsson-Payant B, Han Y, Jaffré F, Zhu J, et al. SARS-CoV-2 infected cardiomyocytes recruit monocytes by secreting CCL2. Res Sq [Preprint]. 2020 Nov 17:rs.3.rs-94634. https://doi.org/10.21203/rs.3.rs-94634/v1.

87. Pérez-Bermejo JA, Kang S, Rockwood SJ, Simoneau CR, Joy DA, Ramadoss GN, et al. SARS-CoV-2 infection of human iPSC-derived cardiac cells predicts novel cytopathic features in hearts of COVID-19 patients. bioRxiv [Preprint]. 2020 Sep 12: 2020.08.25.265561. https://doi.org/10.1101/2020.08.25.265561 Update in: Sci Transl Med. 2021 Mar 15.

88. Yao XH, Li TY, He ZC, Ping YF, Liu HW, Yu SC, et al. A pathological report of three COVID-19 cases by minimal invasive autopsies. Zhonghua bing li xue za zhi $=$ Chinese $\mathrm{J}$ Pathol [Internet]. 2020;49:411-7 Available from: http://www.ncbi.nlm. nih.gov/pubmed/32172546.

89. Sala S, Peretto G, Gramegna M, Palmisano A, Villatore A, Vignale D, et al. Acute myocarditis presenting as a reverse Tako-Tsubo syndrome in a patient with SARS-CoV-2 respiratory infection. Eur Heart J [Internet]. 2020;41:1861-2 Available from: http://www.ncbi.nlm.nih.gov/pubmed/32267502.

90. Clark DE, Parikh A, Dendy JM, Diamond AB, George-Durrett K, Fish FA, et al. COVID-19 myocardial pathology evaluated through scrEening cardiac magnetic resonance (COMPETE CMR). medRxiv [Preprint]. 2020 Sep 2:2020.08.31.20185140. https://doi.org/10.1101/2020.08.31.20185140 Update in: Circulation. 2020 Dec 17.

91. Knight DS, Kotecha T, Razvi Y, Chacko L, Brown JT, Jeetley PS, et al. COVID-19: Myocardial Injury in Survivors. Circulation [Internet]. 2020;142:1120-2 Available from: http://www.ncbi. nlm.nih.gov/pubmed/32673505.

92. Puntmann VO, Carerj ML, Wieters I, Fahim M, Arendt C, Hoffmann J, et al. Outcomes of Cardiovascular Magnetic Resonance Imaging in Patients Recently Recovered From Coronavirus Disease 2019 (COVID-19). JAMA Cardiol [Internet]. 2020;5:1265-73 Available from: http://www.ncbi. nlm.nih.gov/pubmed/32730619.

93. Trogen B, Gonzalez FJ, Shust GF. COVID-19-Associated Myocarditis in an Adolescent. Pediatr Infect Dis J [Internet]. 2020;39:e204-5 Available from: http:/www.ncbi.nlm.nih.gov/ pubmed/32502128.

94. Doyen D, Moceri P, Ducreux D, Dellamonica J. Myocarditis in a patient with COVID-19: a cause of raised troponin and ECG changes. Lancet (London, England) [Internet]. 2020;395:1516 Available from: http://www.ncbi.nlm.nih.gov/pubmed/32334650.

95. Inciardi RM, Lupi L, Zaccone G, Italia L, Raffo M, Tomasoni D, et al. Cardiac Involvement in a Patient With Coronavirus Disease 2019 (COVID-19). JAMA Cardiol [Internet]. 2020;5:819-24 Available from: http://www.ncbi.nlm.nih.gov/pubmed/32219357. 
96. Kim I-C, Kim JY, Kim HA, Han S. COVID-19-related myocarditis in a 21-year-old female patient. Eur Heart $\mathbf{J}$ [Internet]. 2020;41:1859 Available from: http://www.ncbi.nlm.nih.gov/ pubmed/32282027.

97. Luetkens JA, Homsi R, Dabir D, Kuetting DL, Marx C, Doerner J, et al. Comprehensive Cardiac Magnetic Resonance for ShortTerm Follow-Up in Acute Myocarditis. J Am Heart Assoc [Internet]. 2016;5:e003603 Available from: http://www.ncbi. nlm.nih.gov/pubmed/27436306.

98. Lemos ACB, do Espírito Santo DA, Salvetti MC, Gilio RN, Agra LB, Pazin-Filho A, et al. Therapeutic versus prophylactic anticoagulation for severe COVID-19: a randomized phase II clinical trial (HESACOVID). Thromb Res [Internet]. 2020;196:35966 Available from: http://www.ncbi.nlm.nih.gov/pubmed/ 32977137.

99. Wang M, Cao R, Zhang L, Yang X, Liu J, Xu M, et al. Remdesivir and chloroquine effectively inhibit the recently emerged novel coronavirus (2019-nCoV) in vitro. Cell Res [Internet]. 2020;30: 269-71 Available from: http://www.ncbi.nlm.nih.gov/pubmed/ 32020029.

100. Wang Y, Zhang D, Du G, Du R, Zhao J, Jin Y, et al. Remdesivir in adults with severe COVID-19: a randomised, double-blind, placebo-controlled, multicentre trial. Lancet (London, England) [Internet]. 2020;395:1569-78 Available from: http://www.ncbi. nlm.nih.gov/pubmed/32423584.

101. Wilt TJ, Kaka AS, MacDonald R, Greer N, Obley A, Duan-Porter W. Remdesivir for Adults With COVID-19: A Living Systematic Review for American College of Physicians Practice Points. Ann Intern Med [Internet]. 2021;174:209-20 Available from: http:// www.ncbi.nlm.nih.gov/pubmed/33017170.

102. WHO Solidarity Trial Consortium, Pan H, Peto R, HenaoRestrepo A-M, Preziosi M-P, Sathiyamoorthy V, et al. Repurposed Antiviral Drugs for Covid-19 - Interim WHO Solidarity Trial Results. N Engl J Med [Internet]. 2021;384: 497-511 Available from: http://www.ncbi.nlm.nih.gov/pubmed/ 33264556 .

103. Clementi N, Ferrarese R, Criscuolo E, Diotti RA, Castelli M, Scagnolari C, et al. Interferon- $\beta$-1a Inhibition of Severe Acute Respiratory Syndrome-Coronavirus 2 In Vitro When Administered After Virus Infection. J Infect Dis [Internet]. 2020;222:722-5 Available from: http://www.ncbi.nlm.nih.gov/ pubmed/32559285.

104. Zhang Q, Bastard P, Liu Z, Le Pen J, Moncada-Velez M, Chen J, et al. Inborn errors of type I IFN immunity in patients with lifethreatening COVID-19. Forensic Sci Int. 2020;370:eabd4570 Available from: http://www.ncbi.nlm.nih.gov/pubmed/32972995.

105. Bastard P, Rosen LB, Zhang Q, Michailidis E, Hoffmann H-H, Zhang Y, et al. Autoantibodies against type I IFNs in patients with life-threatening COVID-19. Forensic Sci Int. 2020;370:eabd4585 Available from: http://www.ncbi.nlm.nih.gov/pubmed/32972996.

106. Hung IF-N, Lung K-C, Tso EY-K, Liu R, Chung TW-H, Chu M$\mathrm{Y}$, et al. Triple combination of interferon beta-1b, lopinavir-ritonavir, and ribavirin in the treatment of patients admitted to hospital with COVID-19: an open-label, randomised, phase 2 trial. Lancet (London, England) [Internet]. 2020;395:1695-704 Available from: http:/www.ncbi.nlm.nih.gov/pubmed/32401715.

107. Monk PD, Marsden RJ, Tear VJ, Brookes J, Batten TN, Mankowski M, et al. Safety and efficacy of inhaled nebulised interferon beta-1a (SNG001) for treatment of SARS-CoV-2 infection: a randomised, double-blind, placebo-controlled, phase 2 trial. Lancet Respir Med [Internet]. 2021;9:196-206 Available from: http://www.ncbi.nlm.nih.gov/pubmed/33189161. Recombinant interferon use may present as a therapeutic opportunity in patients with SARS-CoV-2 infection and associated myocarditis akin to prior animal studies.

108. Yao X, Ye F, Zhang M, Cui C, Huang B, Niu P, et al. In Vitro Antiviral Activity and Projection of Optimized Dosing Design of Hydroxychloroquine for the Treatment of Severe Acute Respiratory Syndrome Coronavirus 2 (SARS-CoV-2). Clin Infect Dis [Internet]. 2020;71:732-9 Available from: http:// www.ncbi.nlm.nih.gov/pubmed/32150618.

109. Tang W, Cao Z, Han M, Wang Z, Chen J, Sun W, et al. Hydroxychloroquine in patients with mainly mild to moderate coronavirus disease 2019: open label, randomised controlled trial. BMJ [Internet]. 2020;369:m1849 Available from: http://www. ncbi.nlm.nih.gov/pubmed/32409561.

110. Cavalcanti AB, Zampieri FG, Rosa RG, Azevedo LCP, Veiga VC, Avezum A, et al. Hydroxychloroquine with or without Azithromycin in Mild-to-Moderate Covid-19. N Engl J Med [Internet]. 2020;383:2041-52 Available from: http://www.ncbi. nlm.nih.gov/pubmed/32706953.

111. Self WH, Semler MW, Leither LM, Casey JD, Angus DC, Brower $\mathrm{RG}$, et al. Effect of Hydroxychloroquine on Clinical Status at 14 Days in Hospitalized Patients With COVID-19: A Randomized Clinical Trial. JAMA [Internet]. 2020;324:2165-76 Available from: http://www.ncbi.nlm.nih.gov/pubmed/33165621.

112. Angus DC, Derde L, Al-Beidh F, Annane D, Arabi Y, Beane A, et al. Effect of Hydrocortisone on Mortality and Organ Support in Patients With Severe COVID-19: The REMAP-CAP COVID-19 Corticosteroid Domain Randomized Clinical Trial. JAMA [Internet]. 2020;324:1317-29 Available from: http://www.ncbi. nlm.nih.gov/pubmed/32876697.

113. Dequin P-F, Heming N, Meziani F, Plantefève G, Voiriot G, Badié $\mathrm{J}$, et al. Effect of Hydrocortisone on 21-Day Mortality or Respiratory Support Among Critically Ill Patients With COVID19: A Randomized Clinical Trial. JAMA [Internet]. 2020;324: 1298-306 Available from: http://www.ncbi.nlm.nih.gov/ pubmed/32876689.

114. CMP J, MEL F, FFA V, Sampaio VS, MAA A, Melo GC, et al. Methylprednisolone as adjunctive therapy for patients hospitalized with coronavirus disease 2019 (COVID-19; Metcovid): a randomized, double-blind, phase IIb, placebo-controlled trial. Clin Infect Dis. 2021 May 4;72(9):e373-81. https://doi.org/10.1093/cid/ ciaa1 177.

115. Fisher CJ, Dhainaut JF, Opal SM, Pribble JP, Balk RA, Slotman GJ, et al. Recombinant human interleukin 1 receptor antagonist in the treatment of patients with sepsis syndrome. Results from a randomized, double-blind, placebo-controlled trial. Phase III rhIL-1ra Sepsis Syndrome Study Group. JAMA [Internet]. 1994;271:1836-43 Available from: http://www.ncbi.nlm.nih. gov/pubmed/8196140.

116. Shakoory B, Carcillo JA, Chatham WW, Amdur RL, Zhao H, Dinarello CA, et al. Interleukin-1 Receptor Blockade Is Associated With Reduced Mortality in Sepsis Patients With Features of Macrophage Activation Syndrome: Reanalysis of a Prior Phase III Trial. Crit Care Med [Internet]. 2016;44:275-81 Available from: http://www.ncbi.nlm.nih.gov/pubmed/26584195.

117. Cavalli G, De Luca G, Campochiaro C, Della-Torre E, Ripa M, Canetti D, et al. Interleukin-1 blockade with high-dose anakinra in patients with COVID-19, acute respiratory distress syndrome, and hyperinflammation: a retrospective cohort study. Lancet Rheumatol [Internet]. 2020;2:e325-31 Available from: http:// www.ncbi.nlm.nih.gov/pubmed/32501454.

118. Ucciferri C, Auricchio A, Di Nicola M, Potere N, Abbate A, Cipollone $\mathrm{F}$, et al. Canakinumab in a subgroup of patients with 
COVID-19. Lancet Rheumatol [Internet]. 2020;2:e457-ee458 Available from: http://www.ncbi.nlm.nih.gov/pubmed/32835251.

119.• Cremer PC, Sheng C, Sahoo D, Dugar S, Aguillon-Prada R, Hernandez-Montfort J, et al. Canakinumab to Reduce Deterioration of Cardiac and Respiratory Function in Sars-cov2 Associated Myocardial Injury With Heightened Inflammation (canakinumab in Covid-19 Cardiac Injury): Results From the Randomized Three C Study. Late-Breaking. Sci Abstr Featur Sci Abstr From Am Hear Assoc Sci Sess 2020 [Internet]. Available from: https://www.ahajournals.org/doi/10.1161/CIR. 0000000000000940. In patients with cardiac injury, this study showed that patients with high dose canakinumab were numerically more likely to demonstrate clinical recovery at 28 days.

120. Malgie J, Schoones JW, Pijls BG. Decreased mortality in coronavirus disease 2019 patients treated with tocilizumab: a rapid systematic review and meta-analysis of observational studies. Clin Infect Dis. 2021 Jun 1;72(11):e742-9. https://doi.org/10.1093/ cid/ciaa1445.

121. Gupta S, Wang W, Hayek SS, Chan L, Mathews KS, Melamed ML, et al. Association Between Early Treatment With Tocilizumab and Mortality Among Critically Ill Patients With COVID-19. JAMA Intern Med [Internet]. 2021;181:41-51 Available from: http://www.ncbi.nlm.nih.gov/pubmed/33080002.

122. Stone JH, Frigault MJ, Serling-Boyd NJ, Fernandes AD, Harvey L, Foulkes AS, et al. Efficacy of Tocilizumab in Patients Hospitalized with Covid-19. N Engl J Med [Internet]. 2020;383:
2333-44 Available from: http://www.ncbi.nlm.nih.gov/pubmed/ 33085857.

123. The REMAP-CAP Investigators. Interleukin-6 Receptor Antagonists in Critically Ill Patients with Covid-19Preliminary report. Unpubl Work. 2021;

124. Li L, Zhang W, Hu Y, Tong X, Zheng S, Yang J, et al. Effect of Convalescent Plasma Therapy on Time to Clinical Improvement in Patients With Severe and Life-threatening COVID-19: A Randomized Clinical Trial. JAMA [Internet]. 2020;324:460-70 Available from: http://www.ncbi.nlm.nih.gov/pubmed/32492084.

125. Agarwal A, Mukherjee A, Kumar G, Chatterjee P, Bhatnagar T, Malhotra P, et al. Convalescent plasma in the management of moderate covid-19 in adults in India: open label phase II multicentre randomised controlled trial (PLACID Trial). BMJ [Internet]. 2020;371:m3939 Available from: http://www.ncbi. nlm.nih.gov/pubmed/33093056.

126. Joyner MJ, Senefeld JW, Klassen SA, Mills JR, Johnson PW, Theel ES, et al. Effect of Convalescent Plasma on Mortality among Hospitalized Patients with COVID-19: Initial ThreeMonth Experience. medRxiv Prepr Serv Heal Sci [Internet]. 2020; Available from: http://www.ncbi.nlm.nih.gov/pubmed/ 32817978 .

Publisher's Note Springer Nature remains neutral with regard to jurisdictional claims in published maps and institutional affiliations. 